\title{
Correction to: Transpiration and growth of young African mahogany plants subject to different water regimes
}

\author{
Derblai Casaroli ${ }^{1}$ (1) - Ana Cláudia Oliveira Sérvulo ${ }^{2} \cdot$ Lucas Melo Vellame $^{3} \cdot$ José Alves Júnior $^{1}$. \\ Adão Wagner Pêgo Evangelista ${ }^{1} \cdot$ Marcio Mesquita ${ }^{1} \cdot$ Rilner Alves Flores $^{1}$
}

Published online: 21 October 2019

(C) ISB 2019

\section{Correction to: International Journal of Biometeorology https://doi.org/10.1007/s00484-019-01771-5}

The original article was erroneously published with the contributor name Ana Cláudia Sérvulo. The publisher and author group of the article would like all to know that the contributor name should instead be presented and be recognized as Ana Cláudia Oliveira Sérvulo and not the former. This correction stands to correct the original article and the original article has been corrected.

Publisher's note Springer Nature remains neutral with regard to jurisdictional claims in published maps and institutional affiliations.
The online version of the original article can be found at https://doi.org/ 10.1007/s00484-019-01771-5

Derblai Casaroli

derblai@ufg.br

Ana Cláudia Oliveira Sérvulo

anaclaudiaoservulo@hotmail.com

Lucas Melo Vellame

lucasvellame@gmail.com

José Alves Júnior

jose.junio@pc.cnpq.br

Adão Wagner Pêgo Evangelista

awpego@pq.cnpq.br

\author{
Marcio Mesquita \\ marciomes@gmail.com \\ Rilner Alves Flores \\ rilner1@hotmail.com \\ 1 Federal University of Goiás, Goiânia GO Brazil \\ 2 Evangelical Faculty of Goianésia, Goianésia GO Brazil \\ 3 Federal University of Bahia Recôncavo, Salvador Bahia Brazil
}

